\title{
Analyzing Errors on The Use of Past Tense in Argumentative Writing of Tenth Grade Students At SMAN 2 Fakfak West Papua
}

\author{
Wa Nursila' ${ }^{1}$, Ramli $^{2}$, Sudirman $^{2}$ \\ ${ }^{1}$ Magister Bahasa Inggris Program Pascasarjana, Universitas Bosowa \\ ${ }^{2}$ Program Studi Studi Bahasa Inggris, Program Pascasarjana, Universitas Bosowa
}

E-mail: wanursila@gmail.com

Diterima: 14 Juli 2020/Disetujui 07 Desember 2020

\begin{abstract}
Abstrak. Tujuan penelitian ini adalah untuk mengidentifikasi jenis kesalahan menulis karangan argumentasi dengan menggunakan kata lampau di SMAN 2 FakFak. Klasifikasi jenis kesalahan dalam penelitian ini berdasarkan pada prosedur yang dibuat oleh Dulay dan analisis kesalahan menggunakan prosedur yang dibuat oleh Ellis. Penelitian ini menggunakan pendekatan analisis deskripsi dalam menjelaskan dan menganalisis kesalahan data yang diperoleh. Data peneltian diperoleh berdasarakan hasil tes siswa pada penggunaan kata lampau. Sampel penelitian ini adalah siswa kelas X SMAN 2 FakFak periode akademik 2020/2021, Kelas X IPA 1 terdiri dari 12 siswa. Analisis data dilakukan dengan mengidentifikasi dan menganalis hasil tes siswa. Hasil penelitian menunjukkan bahwa hampir semua siswa melakukan kesalahan dalam menulis karangan argumentasi dengan menggunakan kata lampau. Siswa kurang memahami dan memperhatikan perubahan kata kerja dan bentuk masa lalu yang berkelanjutan. Mereka membuat kesalahan di bagian tambahan, kelalaian, kesalahan informasi dan salah urus. Oleh karena itu disarankan kepada siswa untuk lebih giat lagi menulis sehingga dapat meminimalisir kesalahan dalam penulisan karangan argumentasi.
\end{abstract}

Kata Kunci: Analisis Kesalahan, Penggunaan Kata Lampau, Karangan Argumenstasi, Fakfak

\begin{abstract}
The objective of this study was to identify types of errors in the use of past tense in an argumentative writing at SMAN 2 FakFak. The classification of the types of errors in this study was based on procedure made by Dulay and the error analysis procedure made by Ellis. This study used descriptive analysis method to describe and analyse the errors of the data collected. The data were collected from students' tests in the use of Simple Past Tense. The sample of this study was tenth grade students of SMAN 2 FakFak, academic year 2020/2021, the class of X IPA 1 consisting of 12 students. Data analysis was done by identifying and analysing the students' tests. The results show that most of students made an error when writing an argumentative writing using past tense. They did not understand and pay attention on verb changes in past tense and past continuous. The students also made errors in addition parts, omission, malformation and disordering. Therefore, it is suggested for students to frequently practice in argumentative writing in order to minimize mistakes.
\end{abstract}

Keywords: Error Analysis, Simple Past Tense, Argumentative Writing, Fakfak

\section{Introduction}

Writing is important and essential skills for English learners (Lasaten, 2014). In learning writing, students should practice their writing in order to let them develop this skill. The students should be able to think about ideas then express them in the written form. Since writing is difficult, teachers must give some strategies and practices in teaching writing. Nowadays, some English teachers in SMAN 2 FakFak still teach writing to students by using lecturing method without combining it with other methods. It causes less interaction between students-teachers or students-students. Teachers often just ask students to write without giving a clear explanation and instruction about the writing, or do the writing tasks in the textbook or students' work.

In learning a foreign language, an error plays an important role. Students still have to learn to determine their level of language system and discover their errors. According to Sermsook et al. (2017), teachers should realize errors made by students. There should be at least two stages of activities carried out in error analysis. The first is identifying and analysing errors based on the type of errors. Types of errors include omission, addition, malformation, and disordering. Azar (2012) stated that simple past tense explains the activities or situations that ended in the past. Based on a study by Azar (2011), most students confused to add regular and irregular verb. The research similarities are error analysis in using simple past tense in an argumentative writing but this study analysed the error through the surface structure taxonomy.

Based on the preliminary observation conducted at SMAN 2 FakFak, it was found that the English teacher often finds their students unable to express their ideas in writing. This was experienced by English teacher of SMAN 2 FakFak who stated three main problems in writing faced by the students; lack of ideas, poor in grammar and mother tongue interference. Related to the situation happening at SMAN 2 FakFak, there has been a preliminary research conducted in the tenth-grade students of SMAN 2 FakFak. In this preliminary research, a diagnostic test was administered to measure students' performance especially argumentative and procedural writing. The present researcher found that most of the students are in 
"fair" and "poor" level. So that, from the result, it can be concluded that it is still far away left from the curriculum expectation in writing subject. Referring to the curriculum being implemented at SMAN 2 FakFak, it is found that the curriculum 2013 demanded writing class which is in contrast to students' achievement. This research focused on students argumentative writing using past tense.

This study intended to analyse the students of SMAN 2 FakFak West Papua who are at the third year to overcome their inability in writing class. This research focuses on error analysis in argumentative paragraph to find out errors made by students because it was shown in their syllabus that argumentative paragraph is taught in the third grade. Therefore, this research was urgent to carry out to find out a solution of the problem. Apart from the importance, urgency, and novelty, this study was feasible to conduct at SMAN 2 FakFak West Papua.

This research aims to find out error types of past tense in argumentative writing at SMAN 2 FakFak. The result of the study was expected to give contribution to theoretical development/ refinement of ELT in writing. The teacher also checked and analysed students' errors using past tense. This research could be used in helping students by practice make an argumentative writing using past tense. By content, the writer focused on error analyses using past tense in argumentative writing text. By activity, this research provided argumentative writing which meant that the writer gave a topic of argumentative writing. The writer analysed the errors of simple past, past continues, past perfect, and past continues tense.

\section{Research Method}

This research applied descriptive qualitative method. Qualitative data sources included observation dan writing texts. This study analysed and classified students' errors in argumentative writing. It described the number of errors in the table form as recapitulation of the error that the students have made in each sentence and gave reconstruction of whole composition. The sample was the ninth-grade students of SMAN 2 FakFak from class X IPA 1, with the total of 12 students. There were two kinds of variable in this research. Independent variable was error analysis on the use of past tense while dependent variable was argumentative writing.

It was a writing test. The students wrote an argumentative under the title "The Last Year on Final Examination". This research analysed students' past tense error to know their ability in argumentative writing text. Burke (2000: 106) states that validity is a judgment based on a test or assessment procedures. To measure the validity, expert judgment was used to validate the writing test. The expert judged whether a test instrument has high validity and the test was based on the given materials. This is necessary to identify whether the research instrument was valid and reliable before applying it in the classroom.

There were some procedures in data analysis. Student's writing tests were analysed. Besides that, types of errors in the writing test were classified. The error sentences were classified in each of errors columns and corrected it.

\section{Result dan Discussion}

The data were collected by giving a test. Some errors made by the students using Past Tense in argumentative writing were found. Based on the writing test, results show that most of the students made grammatical errors at SMAN 2 FakFak. Primarily research found that students made errors in argumentative writing. The results showed that students of X IPA 1 felt confused to understand pattern of simple past. The students were able to change adjective to verb form. Thus, they could not identify regular and irregular verb. The problem was when the teacher explained the material, the student did not pay attention. As a consequence, the test result was poor. It was related with 2013 curriculum because learning of tenses must be integrated. The teacher said that the students were still confused when just given explanation without examples. Moreover, by adding other method, it made students unable to apply simple past in Argumentative writing. The results of students writing test of X IPA 1 was poor. The students thought that they did not know the meaning and lack of vocabularies to write. Besides that, they did not know about verb. The students said that they did not know verb in Indonesia and English as well. Some of the students said that they were still confused using simple past tense.

Students' Argumentative writing was analysed by identifying errors, types of errors, content of explanation and sentences correction. The data were collected and the results showed that students of class X IPA 1 almost entirely made errors in Argumentative Writing. From the test result of errors and observation analysis, several aspects caused errors made by students in argumentative writing. The results showed that students unable to translate words because of lack of vocabularies. The students did not know structural using tenses in writing Argumentative Writing. Besides that, the students are lack on tenses in their writing. Moreover, there were some factor which influenced English teachers. For instance, teacher did not use an instrument to explain the subject. Otherwise, some students did not pay attention. The students' Argumentative writing was analyzed which referred to identification of errors, types of errors, content of explanation and sentence correction. Therefore, error analysis could help English teacher to find other teaching media or technique to help students when finding difficulties in making sentences and paragraphs. The grammatical errors made by students in Argumentative Writing were checked and analysed.

Related to the previous studies, it was important to describe types of errors in a paragraph and to correct the students' errors and students could learn from their mistakes as an English teacher Error analysis. Besides that, Wati (2011) in her research result found that omission and disordering were in the percentage of 28,9 . Then, the dominant errors were addition. This research was different with the previous research because the dominant errors was malformation. The dominant errors in Wati (2011) was influenced by English teacher who did not aware with error made by students in their writing and they did not check their students' writing. Moreover, the object of previous research was the students of ninth grades who only focused on students' exam procedures. 
The correlation was error analysis. It was supported by the previous study that described about error analysis. It contained the important role to find a solution by the teacher about what to do next in explaining the material. Besides that, in argumentative writing the students could use material correction of their task to find out errors in their assignment. Therefore, if they got writing task, they did not do the same mistakes. Based on the result, it is concluded that most of students of X IPA 1 made errors of past tense in argumentative writing. This study identified errors, types of errors, content of explanation then correct the sentences. Factors that influence the errors in writing such as students unable to change the word, less practice and lack of vocabularies. The students made errors in addition parts, omission, malformation and disordering. The result shows that students X IPA 1 are still poor in using past tense in Argumentative Writing. They need more attention by doing a lot of exercise to improve their argumentative writing.

\section{Conclusions}

The results show that most of students made an error when writing an argumentative writing using past tense. They did not understand and pay attention on verb changes in past tense and past continuous. The students also made errors in addition parts, omission, malformation and disordering. Therefore, it is suggested for students to frequently practice in argumentative writing in order to minimize mistakes.

\section{References}

Abdullah, A. 2013. Error Analysis on The Use of The SimpleTense and The Simple Past Tense in Writing Essays Among TESL College Students.International Journal Education and Research, Vol. 1. Retrieved from http: //www.ijern.com/journal/December-2013/29.pdf, Accessed on January, 20th 2019.

Ahearn, M. Laura. 2012. Living Language: An Introduction to Linguistic Antropology. USA: Blackwell.

Asmiyah, S. 2011. First Step In Paragraph. Putra Media Nusantara. Surabaya.

Azar, Betty S. Hagen.,2012. Fundamental English Grammar, 4nd Edition,New Jersey: Prentice Hall Regents.Retrievedfromonline interactive Software,go to http://www.azarinteractive.com Accessed on January, 20th 2019.

Brown, D. 2000. Principles of Language Learning and Teaching, $4^{\text {th }}$ ed. New York: Logman.

Brown, H. Douglas. 2006. Principles of Language learning and teaching. $5^{\text {th }}$ Edition. New York: Pearson Education logman.

Brown, H.D. 2015. Teaching by principles: An interactive approach to language pedagogy ( $5^{\text {th }}$ ed.). White Pllains, New York:Pearson Education.

Corder,S.P.1974. Error Analysis: Perspectives on Second Language Acquisition. London: Logman

Dulay, Heidi, Marina Burt, and Stephen Krashen.1982. Language Two, New York: Logman

Ellis, Rod.1997. The Study Of Second Language Acquisition. Oxford University Press, New York

Fachrurrazi, 2011. Penerapan Pembelajaran Berbasis Masalah untuk Meningkatkan Kemampuan Berpikir Kritis dan Komunikasi Matematis Siswa Sekolah Dasar. Jurnal Penelitian Pendidikan. Edisi Khusus No.1. Diterbitkan

Fajaryani. Sofi. 2015. The Use of Learning Cell To Improve Students' Writing Skill On Hortatory Exposition Text( A Classroom Action Research in The Eleventh Grade Of State Islamic Senior High School Magelang In The Academic Year 2013/2014.English Department Of Education Teacher Training And Education Faculty Institue For Islamic Srudies (IAIN). Published.

Gould, Erick.1989. The Act of Writing. New York: Random House.

Hermini.2015. Grammatical Error Analysis in Recaount Texts Made by The Students of Cokrominoto University Of Palopo.Post Graduate Program State University of Makassar. Makassar ; State University of Makassar.

Hubbard, Peter, et al. 1983. A Training Course for TEFL. New York: Oxford University Press.

James,Carl.1998. Error in Language Learning and Use: Exploring Error Analysis. London: Logman.

Lasaten,C,Ronald.2014." Analysis of Error in the English Writings of Teacher Education',dalamkajian linguistic,Vol.5, No.3.2014.p.1.

Ma'mun, Nadiah. 2016. The Grammatical Error on The Paragraph Writing.UinWalisongo. Semarang journal Vision.

Raimes, Ann.1983.Technique in Teaching Writing. Oxford. Oxford University Press

Richards, Jack C and Richard Schmidt. 2010. Longman Dictionary of Language Teaching and Applied Linguistics, 3rd Ed., London: Pearson Education Limited,

Richards, J.C.1974. Error Analysis: Perspectives on Second Language Acquisition. London: Longman.

Saville-Troike, Murrier. 2006. Introducing Second Language Acquistion. Cambridge University Press The Edinburgh Building.United Kingdom

Sermsook, K. Liamnimitr, J. \&Pochakorn, R. 2017. An Analysis of Error in Written English Sentences: A Case Study of Thai EFL Students. English Language Teaching; Canadian Center of Science and Education, 10 (3).

Syarif, R. 2014. An Error Analysis On Students Simple Past Mastery In Their Text (Thesis, State Islamic University Syarif Hidayatullah, Jakarta).Retrievedfromhttp://repository.uinjkt.ac.id/dspace/handle/123456789/25366, Accessed on March, 14th 2019

Wahyuni, Mochtar Marhum and Muhsin.2014.Analysis Error Made by the Grade VIII in Witing recount Text Adopted From http.www.e-JounalofEnglishLanguageTeachingSociety(ELTS).Vol.2No32014_ISSN-Retrieved on January $24^{\text {th }} 2019$ 